<原 著 $>$

ハローセン肝障害発症に打けるハローセン代謝と低酸素の役割

ーラット動脈血ガス分析を中心としてー

$\begin{array}{llllll}\text { 波多野 等 } & \text { 野村 } & \text { 文夫 } & \text { 塚本 俊彦 } & \text { 三島 } & \text { 昭彦 } \\ \text { 中山 隆雅 } & \text { 斉藤 } & \text { 正之 } & \text { 飯田 真司 } & \text { 高円 } & \text { 博文* } \\ \text { 長谷川浩平 } & \text { 飯島 } & \text { 一彦** } & \text { 大西久仁彦 } & \text { 奥田 } & \text { 邦雄* }\end{array}$

要 旨：ラット，八ローセン肝障害モデルに怙けるハローセン代謝，及び低酸素の役割を明ら かにすることを目的とした。八ローセン麻酔は，フェノバルビタール (PB) 処置群では，吸入 酸素濃度 $\left(\mathrm{FIO}_{2}\right) 14 \%$ の軽度の低酸素下で 2 時間行った。八ローセン麻酔そのるのにより $\mathrm{PaO}_{2}$ の有意の低下が認められたので，その $\mathrm{PaO}_{2}$ の低下を考虑した高度の低酸素のみの群 $\left(\mathrm{FIO}_{2}=\right.$ 10\%)を対照群とした. PB 処置を行ったハローセン麻酔群では中心静脈周囲の肝細胞壊死と血 清 GPT の上昇が認められたのに対し，低酸素のみの群ではいずれも認められなかった. PB 前 投与は，八ローセンの $\mathrm{PaO}_{2}$ 低下作用には影響を及ぼさなかったが，還元経路を量的に反映する 血清弗素イオン濃度を有意に上昇させた。 以上の結果から，ラットハローセン肝障害モデルで は, 肝細胞壊死の発生には低酸素そのものより八ローセンの還元代謝産物の役割が重要である ことが示唆された。

索引用語： 八ローセン肝障害肝小胞体薬物代謝醭素

緒言

八ローセン肝障害は，術後肝障害の主たるものの 1 つであるばかりでなく，薬物性肝障害としても重要で あり，最近鮫島ら゙が報告した過去70年間の薬物性肝 障害症例の検討において子報告例の多かった薬物の上 位薬戌にあげられている。八ローセン肝障害の発症に は，薬剤アレルギーの関与が示唆されているが2)，八 ローセンの代謝産物による過敏性反応の可能性がある こと，又，八ロー七ン毒性代謝産物による直接肝毒性 を示喛する多くの実験結果があることから ${ }^{3.4)}$, 八ロー セン代謝，及び八ローセン肝障害の実験モデルの検討 が必要と思われる，通常用いられるラットハローセン 肝障害モデルでは，薬物代謝酵素誘導と低酸素状態の 両者の存在が必要であり，還元経路による毒性代謝産 物の役割が重視されているが5)，低酸素そのものの役 割を強調する報告むあるあ。. しかしこれら一連の研究 では, 八ローセン麻酔そのものによる，あるいはPBに よる呼吸抑制の結果生じる低酸素状態の影響について は考虑されていない，したがって今回我々は，麻醉中

- 千葉大学医学部第 1 内科

**千葉大学医学部麻酔学教室

<受付日59年 6 月27日 $>$
の血夜ガス分析を中心とし, 麻酔自体, あるいは PBに 上り低酸素状態が増強するか否か，またその低酸素状 態が肝障害発生に影響を及ぼし得るかをハローセン代 謝産物の役割も含め検討を行った。

\section{対象ならびに方法}

実験動物は，体重250g 前後の計58匹の雄性 SD 采 ラットを使用した。飼料は MF(オリエンタル醅母)を 用い，水は自由に与えた。実験を行らにあたってラッ トを次の 4 群に分けて検討を行った。

I 群：ハローセン $1 \%$ ，軽度の低酸素 $\left(\mathrm{FIO}_{2} 14 \%\right)$ ， $\mathrm{PB}$ 末処置 $\mathrm{n}=18$

II 群：ハローセン $1 \%$, 軽度の低酸素 $\left(\mathrm{FIO}_{2} 14 \%\right)$, PB 処置 $n=18$

III群：ハローセン(一), 軽度の低酸素 $\left(\mathrm{FIO}_{2} 14 \%\right)$ ， $\mathrm{PB}$ 末処置 $\mathrm{n}=4$

IV群：ハローセン $(-)$, 高度の低酸素 $\left(\mathrm{FIO}_{2} 10 \%\right)$, $\mathrm{PB}$ 末処置 $\mathrm{n}=18\left(\mathrm{FIO}_{2}=\right.$ 吸入酸素濃度 $)$

肝小胞体分画に認められる薬物代謝䣼素を誘導する 為に, $80 \mathrm{mg} / \mathrm{kg}$ 体重のフェノハルビタール（以下 $\mathrm{PB}$ 之略, $\mathrm{Na}$ 塩)を麻酔を施行する前日までの 4 日間腹腔 内注射を行った。 また，すべてのラットは，麻醉前 14〜16時間は絶食とし，動脈血ガス分析は，大卧動脈 
より採取した血液により, 麻酔前, 麻酔後60分, 90 分, 120分に行った、肝障害の程度は，血清トランスアミ ナーゼ值，組籖学的検討によって評価し，八ローセン の還元代謝産物の産生は, 血清弗素イオン濃度を指標 とした。

八ローセン麻酔は，小動物全身麻酔装置（NAITO 型, SHIN-EI. INDUSTRY, CO, Tokyo）によって行 い, 八ローセン濃度は, 麻酔ガス測定器18型（理研計 器)によって確認した，混合がスとして，ハローセン， 酸素と共に窒素を用いた。麻酔時にラットを最高 6 匹

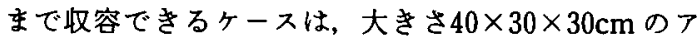
クリル密閉容器を用いた。 その天井部に混合がス流入 孔と，ガス擋拌用のファンを，側面に排気口と，採血 の為の円形孔を6つ設けた。酸素濃度は，排気口から 出る混合ガスを排気管の途中に備えつけた $\mathrm{O}_{2}$ Monitor (Oxygen Monitor, OX 161, 理研計器) によって 測定した。動脈血ガス採血は，大腿動脈にカニューレ を挿入することによって経時的に行った。 カニュレー ションはメーテル麻酔下に行い, 八ローセン麻酔は, エーテル麻䣲から覚醒後少なくと630分後に開始し た. カニューレは, PE 50 (ID: $0.58 \mathrm{~mm}, \mathrm{OD}: 0.965$ $\mathrm{mm}$ )を用いた. 1 回に0.25 0.30m $l$ の採血を行い, 採血後はそれと同量の生理的食塩水を生体内に戻し， 体液量の减少を防いた。血液ガス分析は, Instrumentation Laboratory System 1303. PH/blood gas analyzer (Instrumentation Labolatory, Inc. MA. U.S.A.) によって行った，ハローセン投与群の麻酔前採血は, ハローセン麻酔を施行しない低酸素のみの状態で10分 から15分释過後に採血を行い，60分採血は，八口ーセ ン麻酔を開始後約20分前後で動物の動きが静止する か，その時点を便宜上 0 分として採血を行った.

血清 GPT 值測定には，麻酔後24時間で断頭により 屠殺したラットの血清を用い，トランスフミナーゼ測 定用キット（GO \& GP-transaminase KIT NO 505OP. Sigma Chemical Company, St. Louis, Missori, U.S.A.) によって行った。

血清弗素イオン濃度は, 麻酔直後に屠殺したラット の血清を用いて測定した（弗素電極 IM008F 岩城硝 子, 東京).

組織学的検討を行 らにあたって，肝切片の一部を直 ちに10\% Buffered Formalin 液に固定後，ハララフィン 包埋切片で Hematoxylin Eosin 染色標本を作成した。 組織学的検索では, 倍率100にて10視野を観察し, 組織 学的変化の程度により, Jee らクの方法に準じ, 以下の
如く grade 分類を行った.

$0=$ normal $1=$ mild cell disruption (some dissociation of centrilobular hepatic cords), $<25 \%$ of field area, $2=$ moderate cell disruption, $<50 \%$ of field area, $3=$ extensive cell disruption, $\geqq 50 \%$ of field area, $4=$ occasional cell necrosis, $<25 \%$ of field area, $5=$ extensive cell necrosis, $\geqq 25 \%$ of field area, これらの score に基づいて，各標本の10視野の平均値 を算出し，更に I，II，III群について各 6 匹の平均値 を算出した。

実験結果はMean士SEM で表わし，統計的有意差 は, Student の t-testにより検定した。

\section{結果}

ハローセン麻酔施行時, 及び低酸素下における動眽 血ガス酸素分圧の経時的変化を Fig. 1に示した。， ローセン麻酔前後の酸素分王を比較すると，I 群では 前值 $54 \pm 7 \mathrm{mmHg}$ から 60 分值 $41 \pm 6 \mathrm{mmHg}$ と有意 $(p<$ $0.005) の$ 低下が見られ，II群でる前値 $53 \pm 1 \mathrm{mmHg}$ 560 分値 $42 \pm 3 \mathrm{mmHg}$ と有意 $(\mathrm{p}<0.005)$ の低下が見 られた．しかし，60分以後90分，120分値は，ほとんど 動脈血酸素分圧の変化は認められず, 又その低下の程 度には，I，II群に差はなかった，III群では，前値51士 $2 \mathrm{mmHg}$ から 120 分值 $60 \pm 6$ 至で徐々に直線的な上昇を 続け，I，II群とは全く異った値を示したＩV群の前 值は38 $\pm 2 \mathrm{mmHg} 120$ 分値 $40 \pm 4 \mathrm{mmHg}$ と軽度の上昇 傾向を示しているが, 60 分, 90分, 120 分值に関しては, I，II群との間に有意差が見られなかった。

次に各群間に招ける麻酔後24時間の血清トランスア ミナーゼ値, 麻酔直後の血清弗素イオン濃度を比較検 討した (Fig. 2)。血清トランスフミナーゼ值は，I群

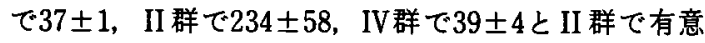
$(\mathrm{p}<0.005)$ の上昇が見られた。血清弗素イオン濃度

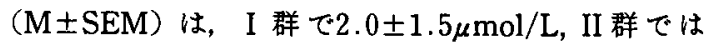
$13.7 \pm 5.1 \mu \mathrm{mol} / \mathrm{L}$ とII群で有意 $(\mathrm{p}<0.005)$ の上昇が 見られたＩV群に関しては，低值の為測定不能であっ た.

Histological score (Fig. 3) は, I 群では0.87士

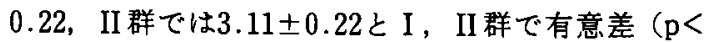
0.005)が見られたが，IV群ではいずれの標本にも明ら かな組織学的変化は見られなかった (Fig. 4). II 群に 拈ける組織像では，肝小葉中心部の壇死が特徴的で， 壊死部に一致して円形細胞を主体とし，一部好中球を 含む細胞浸潤が認められた。, 又, 障害部位の周辺には, 細胞質内に小脂肪滴を認める肝細胞が散見した（Fig. 


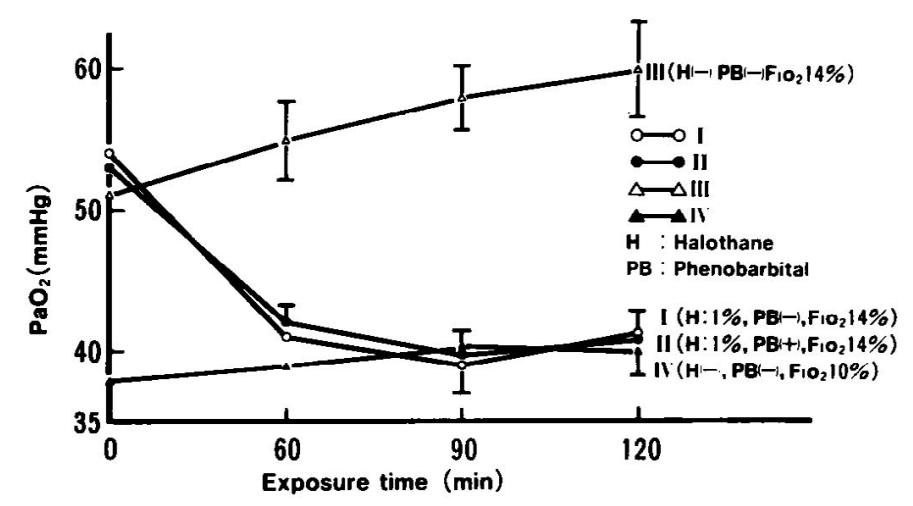

Fig. 1 Change in $\mathrm{PaO}_{2}$ during exposure to halothane and/or hypoxia (Mean \pm SEM). Rats were exposed to $1.0 \%$ halothane under mildly hypoxic atmosphere $\left(\mathrm{FIO}_{2} 14 \%\right)$ for two hours. Halothane aneshesia caused a significant decrease in $\mathrm{PaO}_{2}$ level (Group I). PB pretreatment did not enhance the halothane effects (Group II). Exposure of rats to hypoxic atmosphere resulted in a slight increase in $\mathrm{PaO}_{2}$ (Group III). $\mathrm{PaO}_{2}$ level in rats during exposure to highly hypoxic atmosphere $\left(\mathrm{FiO}_{2} 10 \%\right.$, Group IV) was comparable to that of rats in Groups I and II. $n=6$ in Group I, II and IV. $n=4$ in group III

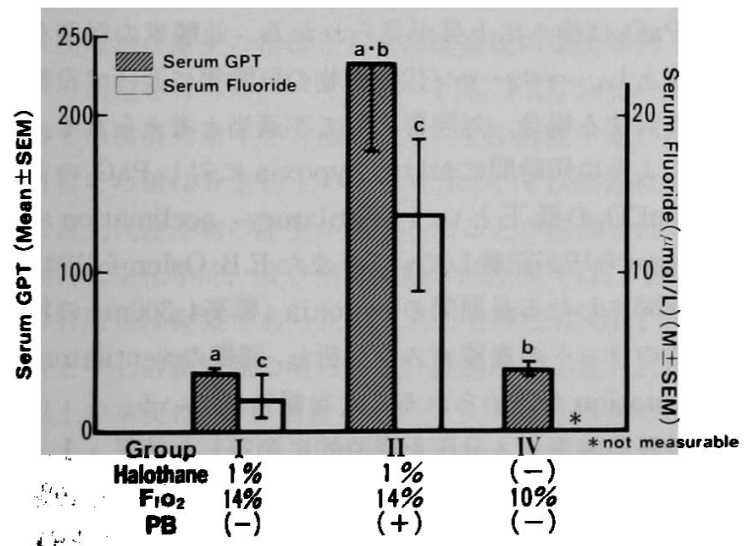

Fig. 2 Serum GPT and serum fluoride levels following exposure to halothane and/or hypoxia. Serum GPT and serurn fluoride levels are significantly elevated in rats exposed to $1.0 \%$ halothane under hypoxic conditions after pretreatment with PB. a : p $<0.005, \mathrm{~b}: \mathrm{p}<0.005$, $c: p<0.005, n=6$ in each group

5).

\section{考按}

1956年 Sucklingによって最初に合成された八ロー 七ンは，気道刺激が少なく，非爆発性であり，導入覚 醒が早いなどの利点をもち，麻䣲菜として広く使用さ れるよらになった。しかし，1958年 Burnap らº゙，，

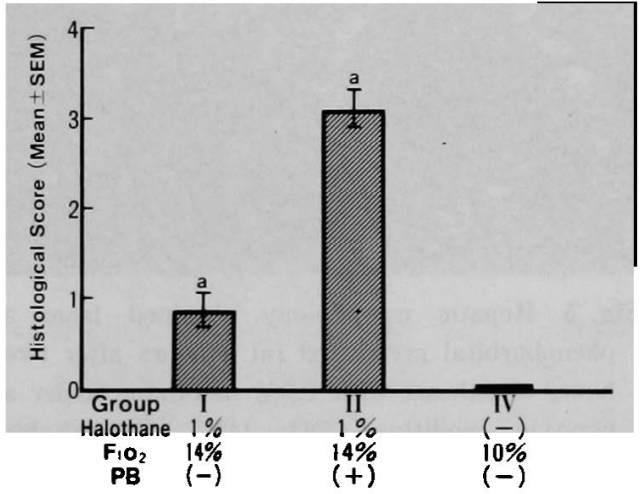

Fig. 3 Effects of phenobarbital pretreatment on halothane-induced hepatotoxicity assessed by histological scores. Rats pretreated with $\mathrm{PB}$ and exposed to $1 \%$ halothane under hypoxic condition $\left(\mathrm{FIO}_{2} 14 \%\right)$ developed marked liver injury, whreras liver injury in rats exposed to highly hypoxic atmosphere was minimal. a: $\mathrm{p}<0.005$ $\mathrm{n}=6$ in each group

ローセン麻酔後に肝障害をきたし死亡した 1 例を報告 して以来同様の報告が相次いだ。この間米国に於て 1959年から1962年に至るまでの 4 年間に85万回の吸入 麻酔薬についての調查が行われた（National Halothane Study $)^{91}$. その結果・ローセン麻醉後の広範性肝 細胞壤死の頻度は, 初回麻醉では 1,000 人に対し1.02人 


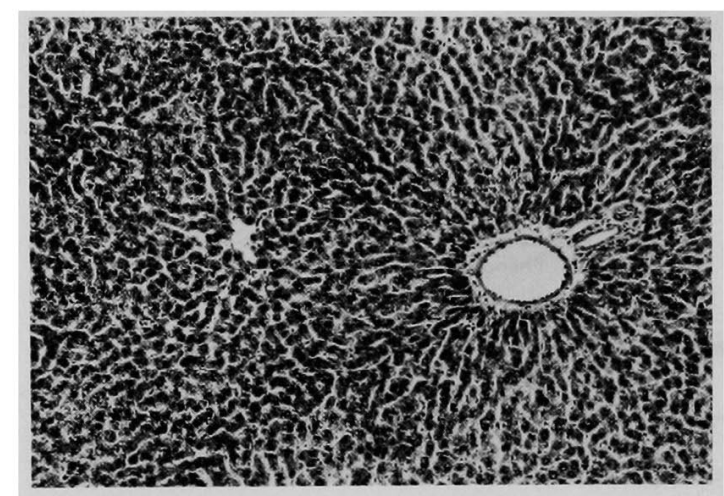

Fig. 4 No significant histological change is observed in rats exposed to highly hypoxic atmosphere without halothane (Group IV). (H \& E, × 100)

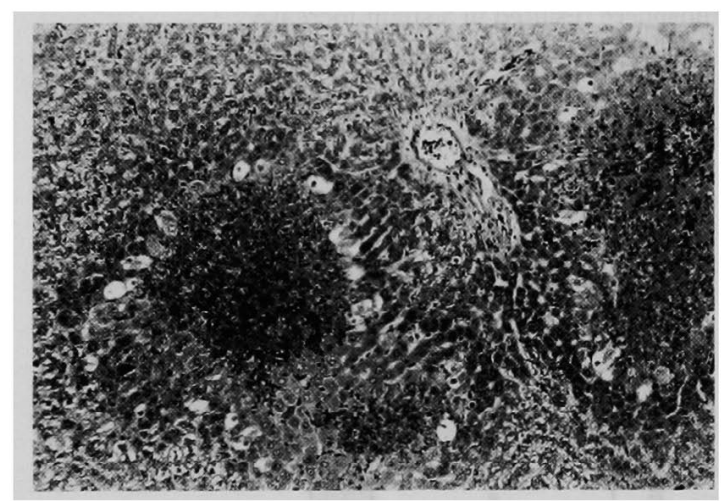

Fig. 5 Hepatic morphology obtained from a phenobarbital pretreated rat 24hours after two hours anesthesia with $1.0 \%$ halothane under a hypoxic condition $\left(\mathrm{FIO}_{2} 14 \%\right)$. Remarkable centrilobular necrosis accompanied by inflam. matory cells is noted. ( $\mathrm{H} \& \mathrm{E} \times 100$ )

であるのに比し， 2 回以上の麻酔では 1,000 人に対し 7.1 人と繰り返し麻酔によって広範性肝細胞壊死が生 しる可能性が高くなることが明らかとなったが，八 ローセン麻酔後の術後死亡率は, 他の麻酥薬の術後死 亡率と大差は見られなかった。しかしこの報告に対し ては，集計方法や軽度の肝障害例が含まれていない点 などに対する批判すあり ${ }^{10)}$ ，軽症例も含めるとその実 数はさらに多くなると考えられ，八ローセン肝障害は 翰血後肝炎とならんで術後肝障害として重要な位置を しめている11. 、ローセン肝障害の発生機序としては, ローセン及びその代謝産物に対する過敏性反応とす る考え方す有力であるが2)，八ローセン毒性代謝産物 の直接肝毒性を示晙する多くの動物実験データがあ $\eta^{2,4)}$ ，八ローセン肝障害モデルの基礎的検討も重要と 考えられる。

PB 処置を行ったラットに低酸素下でハローセン麻 酔を施行すると肝障害をさたすことは知られてい る3,5). しかし八ローセン麻酔そのものにより，あるい はPB投与により低酸素状態がさらに強まり，そのこ とが肝障害発生に何らかの影響を及ぼしている可能性 も考学られる。しかしこのよらにして生じる低酸素状 態と, 肝障害発生との関連については十分な検討がな されていない，今回我々は，動脈血ガス分析を行らこ とにより，八ローセン麻酔施行時と同程度の低酸素群 を設定し，同群を対照として，肝障害発生における低 酸素と八ローセン代謝産物の役割について検討を加兄 た．Fig. 1よりハローセン麻酔によって動脈血ガス分 圧が低下することが明らかであるが，PB 処置によっ てその酸素分圷の低下がさらに増強されることはな かった. $\mathrm{FIO}_{2}$ 14\%下のハローセン麻酔群に対する対照 群として，通常は $\mathrm{FIO}_{2}$ 14\%のみの群が用いられるが， $\mathrm{FIO}_{2} 14 \%$ みの低酸素群では, 2 時間の酸素吸入の結 果 $\mathrm{PaO}_{2}$ は徐々に上昇が見られた為, 低酸素の程度を 一定とし，八ローセン代謝産物の肝障害に及ぼす役割 を検討する場合，対照群として不適当と考えられる. このように短時間における hypoxia に対し $\mathrm{PaO}_{2}$ の上 昇 $\mathrm{PaCO}_{2}$ の低下といら ventilatory acclimationは Shingu ら ${ }^{121}$ が記載している.また E.B. Oslon ら 2 週間にわたる長期間の hypoxia (標高 $4,300 \mathrm{~m}$ ) の状 態でのラットの血液ガスを分析し, 同様の ventilatory adaptation が認められることを報告している.

動脈血酸素ガス分圧を経時的に測定した結果，I， $\mathrm{II}$ 群と同程度の低酸素状態を得る為には， $\mathrm{FIO}_{2}$ を $10 \%$ とする必要があることを見い出した，そこで $\mathrm{FIO}_{2}$ $10 \%$ 群をIV群とし, $\mathrm{PaO}_{2}$ が同レベルの I, II, IV群に ついて肝障害の程度, 代謝産物の量を比較することに より，ハローセン肝障害発生における低酸素，及び八 ローセン代謝産物の各々の役割をより明らかにし得る と考光た。

八ローセン麻酔の呼吸に及ぼす影響について， Burnap $^{8)}$, Severinghaus $5^{14)}$ は tidal volume の低下 を伴った tachypneaによって特徵づけているが, ラッ トを用いた Nishino ら ${ }^{15)}$ 検討によると，呼吸数は八 ローセン麻酔の深度により修飾され, 1.0MAC八ロー センでは呼吸数は $\mathrm{PaCO}_{2}$ の増加と共に減少が見られ たと報告している。我々の検討でるハローセン麻酔に より軽度の $\mathrm{PaCO}_{2}$ の増加が見られ, 呼吸数も麻酔前値 
105前後から麻酔後 90 前後と減少が見られ，ハローセン 麻醉による乎吸抑制が示唆されたが，気道分泌物の増 加による低換気状態も関与していると思われる。 また $\mathrm{FIO}_{2} \quad 10 \%$ の低酸素吸入開始後30分での $\mathrm{PaO}_{2}$ の平均 値は38mmHgであり，L.D. Lewis ら ${ }^{16)}$ とはば同様の 結果を示している.

ハローセンの代謝は，酸化経路と還元経路の 2 つの 経路が考えられており, 酸化代謝産物として bromide, chloride, trifluoroacetic acid 等か，還元代謝産物とし 乙fluoride, 2-chloro-1,1,1-trifluoroethane (CTF), 2-chloro-1,1-difluoroethylene (CDF) 等が知られてい る.このうち肝毒性に働くのは，還元释路の中間代謝 産物と考えられている，例えば Widger ら ${ }^{17} は \mathrm{~PB}$ 処 置を施したラットに低酸素下で八ロー七ン麻醉を行う と, 肝障害が見られると同時に還元代謝産物を量的 に反映すると考えられる血清弗素イオン濃度が有意 に上昇し，また，嫌気的条件下に括ける ${ }^{14} \mathrm{C}$-halothane metabolites $の$ microsomal macromolecules への共 有結合が上昇していることを示した. 今回我々も還元 代謝産物の産生の指標として麻醉直後の血清弗素イオ ンの測定を行った。ハローセン $1 \%, \mathrm{FIO}_{2} 14 \%$ の第 $\mathrm{I}$ 群での血清弗素イオン值に比し，PB 処置を施した第 II 群での値は 6 倍以上の上昇を示し, PB 処置によっ て還元代謝産物の産生が高まったことが推測される。 同時に生化学的, 及び病理組織学的所見では, I 群で の肝障害は軽微であったのに対しII 群では GPT の上 梨と中心静脈周囲の明らかな肝細胞壊死が見られた。 以上の事実は，PB 前投与と八ローセン肝障害の密接 なかかわりを示唆するが，前述の如くPB 前投与は八 ローセンによる $\mathrm{PaO}_{2}$ の変化に影響を及ぼさなかった ことから，PB 前投与はその薬物代謝醅素誘導作用を 介してハローセン肝障害を増強させるるのと考えられ る. 我々は還元経路の指標として, 血清弗素イオン濃

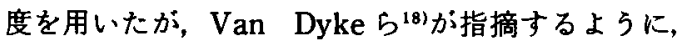
microsomal phospholipids と結合している代謝産物 のうち脱弗素ハローセン代謝産物はおよそ60\%にすぎ ないとされ，肝障害の成因について論ずる場合は他の 還元代謝産物, 酸化代謝産物の測定, 肝障害の程度と の相関等について検討することも重要と考えられる.

Shingu 5は6,19)，還元代謝産物が肝障害発生に何ら かの影響を及ぼしているとしながらす，肝障害発生に は低酸素状態が上り重要であることを強調している。

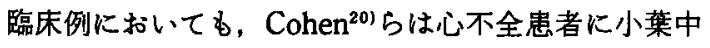
心部の壊死が認められる例を報告し、これらの is- chemic hepatits の成因については venous congestionよりる， liver perfusion の障害が主に関与してい

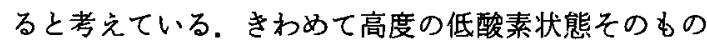
により肝障害が引きおこされる事については異論はな いと思われるが，八ローセンによる $\mathrm{PaO}_{2}$ の低下を考 慮して設定した低酸素群（IV群）においても肝障害が 生じなかったことから，我々の用いたハローセン肝障 害モデルにおいて低酸素の役割は少ないと考えられ る. 従って, PB 処置群で血清弗素イオン濃度が上昇 し，肝障害が強まっていることを考え合わすと，ハロー センによる肝障害発生には八ローセンの還元代謝産物 が関与する可能性が強く示唆される。

稿を終えるにあたり,ラット動脈血採血方法，呼吸生理に ついて御指導, 御助言を賜わった千葉大第二生理学教空林 文明先生に深謝いたします。

\section{文献}

1）酸島美子，塩崎安子，水野孝子，他：日本における 薬物性肝障害の実態. 日消誌 81(1)：37-45, 1984

2) 山口教一, 浪久利彦: 八ローセン肝障害の lymphocytic stimulation test (LTS) とその臨床 的観察. 日消誌 $72: 1023-1031,1975$

3) McLain GE, Sipes IG, Brown BR: An animal model of halothane hepatotoxicity. Anesthesiology $51: 321-326,1979$

4）高木俊和, 石井裕正, 高橋久雄：ハ口-セン麻醉後 の旰障害に関する実㢵的研究一とくに慢性エ夕 ノール投与ラットにおけるハローセン肝焱の発生 について一、「麻醉菜代謝と畈障害 III」盛生倫夫 編, 広島麻醉医学会, 広島, $1982, \mathrm{p} 35-38$

5) Ross WT, Daggy BP, Cardell RR: Hepatic necrosis caused by halothane and hypoxia in phenobarbital-treated rats. Anesthesiology 51 : 327-333, 1979

6) Shingu K, Eger EI, Johnson BH : Hypoxia may be more important than reductive metabolism in halothane-induced hepatic injury. Anesth Analg 61: 824-827, 1982

7) Jee RC, Sipes IG, Gandolfi AJ : Factors influencing halothane hepatotoxicity in the rat hypoxic model. Toxicol Appl Pharmacol 52 : 267-277, 1980

8) Burnap TK, Galla ST, Vandam LD: Anesthetic, circulatory and respiratory effects of 
fluothane. Anesthesiology $19: 307-320,1958$

9) Subcomittee on the National Halothane Study on the Comittee on Anesthesia, National Academy of Sciences-National Research Council. Cooperative Study. Summary of the National Halothane Study: Possible association between halothane anesthesia and postoperative hepatic necrosis. JAMA 197: 775-788, 1966

10) Touloukian J, Kaplowitz N: Halothane-induced hepatic disease. Seminars in Liver Disease $1(2): 134-141,1981$

11）清野清一：麻酔と肝障害。「肝障害と手術」. 菅原克 彦，土屋雅春編，医画薬出版社，東京，1979，p40-46

12) Shingu $K$, Eger EI, Johnson BH : Effects of halothane, isoflurane, enflurane, thiopental, and fentanyl on blood gas values in rats exposed to hypoxia. Anesth Analg 62:155-159, 1983

13) Oslon EB, Dempsey JA: Rat as a model for humanlike ventilatory adaptation to chronic hypoxia. J Appl Physiol 44 : 763-769, 1978

14) Severinghaus JW, Larson CP: Respiration in anesthesia. In: Handbook of physiology, Respiration. Vol II, Edited by Fenn Wo, Rahn H.
Washington DC, American Physiological Society $1219-1264,1965$

15) Nishino $T$, Honda $Y$, Yonezawa $T$ : Sep-rate effects of halothane and carbon dioxide on respiratory duration in vagotomized cats. $\mathrm{Br} \mathbf{J}$ Anaesth 55 : 647-654, 1983

16) Lewis LD, Ponten U, Siesjö BK: Arterial acid-base changes in unanaesthetized rats in acute hypoxia. Respir Physiol 19: 312-321, 1973

17) Widger LA, Gandolfi AJ, Van Dyke RA : Hypoxia and halothane metabolism in vivo. Anesthesiology 44(3) : 197-201, 1976

18) Van Dyke RA, Gandolfi AJ: Anaerobic release of fluoride from halothane-relationship to the binding of halothane metabolites to hepatic cellular constituents. Drug Metab Dispos 4 : 40-44, 1976

19) Shingu K, EgerII EI, Johnson BH : Hypoxia per se produce hepatic damage without death in rats. Anesth Analg 61:820-823, 1982

20) Cohen JA, Kaplan MM : Left-sided heart failure presenting as hepatitis. Gastroenterology $74: 583-587,1978$ 


\title{
Respective roles of hypoxia and halothane metabolites in halothane induced hepatic injury -With special reference to blood gas analysis in rats-
}

\author{
Hitoshi hatano, Fumio Nomura, Toshihiko Tsukamoto, Akihiko Mishima, \\ Takatsune NAKaYama, Masayuki SaIto, Shinji IIDA, Hirofumi KoHEN*, \\ Kohei HaSEgaWA, Kazuhiko IIJIMA**, Kunihiko OHNISHI \\ and Kunio OKUDA*
}

In order to establish the respective roles of halothane metabolites and hypoxia in the rat model of halothane hepatotoxicity, experiments were designed with special reference to blood gas. After pretreatment with phenobarbital $(80 \mathrm{mg} / \mathrm{kg}$, i.p) for four consecutive days, rats were exposed to $1.0 \%$ halothane under a mildly hypoxic condition $\left(\mathrm{FiO}_{2}=14 \%\right)$ for two hours. Since halothane anesthesia caused a significant decrease in $\mathrm{PaO}_{2}$ levels, rats exposed to highly hypoxic atmosphere $\left(\mathrm{FiO}_{2}=10 \%\right)$ in which $\mathrm{PaO}_{2}$ levels were comparable to those in halothane group served as controls. In the halothane group, marked centrilobular necrosis and elevation of SGPT activity were observed, whereas neither significant hitological lesion nor elevation of transaminase activity was noted in the highly hypoxic group. Although phenobarbital treatment did not further decrease the $\mathrm{PaO}_{2}$ levels during halothane anesthesia, serum fluoride level which appears to quantitatively reflect the reductive pathway of halothane metabolism remarkably increased. From these results, we conclude that halothane metabolites rather than hypoxia per se play a major role in the development of halothane induced liver injury in the rat model.

- First Department of Medicine, Chiba University School of Medicine (Chiba)

** Department of Anesthesiology, Medical School of Chiba University (Chiba) 